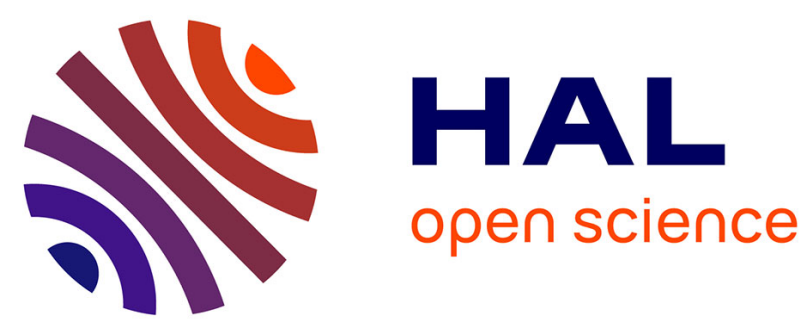

\title{
A new electrochemical sensor based on carbon paste electrode/Ru(III) complex for determination of nitrite: Electrochemical impedance and cyclic voltammetry measurements
}

A. Terbouche, S. Lameche, C. Ait-Ramdane-Terbouche, D. Guerniche, D. Lerari, K. Bachari, D. Hauchard

\section{To cite this version:}

A. Terbouche, S. Lameche, C. Ait-Ramdane-Terbouche, D. Guerniche, D. Lerari, et al.. A new electrochemical sensor based on carbon paste electrode/Ru(III) complex for determination of nitrite: Electrochemical impedance and cyclic voltammetry measurements. Measurement - Journal of the International Measurement Confederation (IMEKO), 2016, 92, pp.524-533. 10.1016/j.measurement.2016.06.034 . hal-01367237

\section{HAL Id: hal-01367237}

https://hal-univ-rennes1.archives-ouvertes.fr/hal-01367237

Submitted on 3 Nov 2016

HAL is a multi-disciplinary open access archive for the deposit and dissemination of scientific research documents, whether they are published or not. The documents may come from teaching and research institutions in France or abroad, or from public or private research centers.
L'archive ouverte pluridisciplinaire HAL, est destinée au dépôt et à la diffusion de documents scientifiques de niveau recherche, publiés ou non, émanant des établissements d'enseignement et de recherche français ou étrangers, des laboratoires publics ou privés. 
A new electrochemical sensor based on carbon paste electrode/Ru(III) complex for determination of nitrite: Electrochemical impedance and cyclic voltammetry measurements.

\author{
Achour TERBOUCHE ${ }^{\mathrm{a}, *}$, Siham LAMECHE ${ }^{\mathrm{a}, \mathrm{b}}$, Chafia AIT-RAMDANE-TERBOUCHE ${ }^{\mathrm{a}}$, Djamila \\ GUERNICHE $^{\mathrm{a}, \mathrm{b}}$, Djahida LERARI ${ }^{\mathrm{a}}$, Khaldoun BACHARI ${ }^{\mathrm{a}}$, Didier HAUCHARD ${ }^{\mathrm{c}, \mathrm{d}}$ \\ ${ }^{a}$ Centre de Recherche Scientifique et Technique en Analyses Physico-chimiques (CRAPC), BP384, Bou-Ismail, \\ RP 42004, Tipaza, Algeria. \\ ${ }^{b}$ Laboratoire d'Electrochimie-Corrosion, Métallurgie et Chimie Minérale, Faculté de Chimie, USTHB \\ University, 16111 Algiers, Algeria \\ ${ }^{c}$ Institut des Sciences Chimiques de Rennes, UMR CNRS 6226, Ecole Nationale Supérieure de Chimie de \\ Rennes, avenue du général Leclerc, CS 50837, 35708 Rennes Cedex 7, France \\ ${ }^{d}$ Université Européenne de Bretagne, 12 avenue Janvier, 35000 Rennes, France \\ *Corresponding author: achour_t@yahoo.fr ; Tel.: +213.778.815.933,
}

fax: +213.24 .325 .774$

\begin{abstract}
The modified carbon paste electrode with $\mathrm{Ru}(\mathrm{III})$ complex was studied as a novel sensor for the determination of nitrite. The behavior of $\mathrm{NO}_{2}^{-}$at the electrode surface was investigated using electrochemical impedance spectroscopy (EIS) and cyclic voltammetry (CV).

EIS provided useful information on the charge transfer resistance $(R)$ at the electrode/solution. The EIS measurements showed that $R$ is low at oxidation potentials, and decreases with increasing temperature. The increase of the constant phase element with temperature is due to the accumulation of nitrite on the electrode, thus, facilitating the electron transfer between electrode and $\mathrm{NO}_{2}{ }^{-}$.

$\mathrm{CV}$ was used to study the effect of $\mathrm{pH}$ on the electro-catalytic oxidation of $\mathrm{NO}_{2}^{-}$and to determine the limit of detection (LOD). CV measurements showed a good linear relationship between the oxidation current and the concentration of $\mathrm{NO}_{2}{ }^{-}$over a wide concentration range $0-1.38 \times 10^{-2} \mathrm{~mol} \mathrm{~L}^{-1}$. Low detection limit of $1.39 \times 10^{-6}$ mol L $\mathrm{L}^{-1}$ towards $\mathrm{NO}_{2}^{-}$was obtained. LOD decreased by $23.2 \%$ compared to that determined using cavity microelectrode.
\end{abstract}


Keywords: Modified carbon paste electrode; Electrochemical impedance spectroscopy; Cyclic voltammetry; Electrochemical measurements; Determination of nitrite ions.

\section{Introduction}

Recently, important studies have been performed on the impact of pollution on the environment and human health [1-3]. Water and food are possible sources of inorganic pollutants [4, 5]. Hence, the development of new effective modified electrodes for the determination of contaminant concentration has become important. However, the use of conventional electrodes (platinum, gold and glassy carbon) can not be used to study electrochemical behaviour of inorganic pollutants because several species may mask the surface of the electrode by inducing a decrease in its sensitivity and accuracy [6].

Several studies have been conducted recently on the impact of inorganic pollutants such as $\mathrm{NO}_{2}^{-}$on water quality [7-13]. To determine these species, different sensors were developed [14-23]. Numerous materials, such as humic acids [7, 24], metallic complexes [25, 26], polymers [27, 28], oxides [29, 30] or films [31, 32] have been used to immobilize different pollutants on the surface of electrodes to use as electrochemical sensors. Indeed, the use of metallic complexes to modify electrodes is very important for applications in the field of electro-analysis. Different supporting carbon materials such as carbon paste and glassy carbon [7,33], carbon fiber [34], carbon nanotube $[35,36]$, carbon film $[37,38]$ and graphite [39] have been used to stabilize electron transfer mediators, primarily due to their low background currents and wide potential windows [40]. The derivatives of the modified carbon electrodes exhibit superior electrochemical properties and demonstrate catalytic activity towards many chemical reactions [35].

Recently, the electrochemical analysis of different elements and species in environment and biological samples has been studied using various sensors based on modified carbon paste electrodes and derivative carbon electrodes. These studies include the determination of heavy metals using modified potentiometric carbon paste electrode based on a novel nano-sensing layer, ionic liquid/graphene modified electrode and potentiometric sensor based on derivative carbon materials [41-43]. Other studies have also developed analysis of drugs and biomolecules using electrochemical sensor based on magnetic multi-walled carbon nanotubes, $\mathrm{Co}_{3} \mathrm{O}_{4}$-reduced graphene oxide modified carbon paste electrode, modified fluorine-doped tin oxide (FTO) aptasensor, $\mathrm{Fe}_{3} \mathrm{O}_{4}$ nanoparticle-decorated reduced graphene oxide modified electrode and high performance magnetite/carbon nanotubes paste electrode [44-48]. 
Electrochemical impedance spectroscopy is often used to study the electrochemical processes at the electrodeelectrolyte interface, reaction mechanisms and kinetics of the electrode [49], and the interfacial properties of the modified electrodes [50-53].

In this paper, we developed an electrochemical sensor to detect nitrite ions $\left(\mathrm{NO}_{2}^{-}\right)$in aqueous solution. The electro catalytic oxidation of $\mathrm{NO}_{2}{ }^{-}$was studied at the modified carbon paste electrode (CPE/Ru(III)-BSAP-PLA), witch was prepared by mixing the ternary Ru(III)-BSAP-PLA complex with graphite powder in paraffin oil.

EIS and $\mathrm{CV}$ techniques were used to measure the change in the charge transfer resistance at the modified electrode at different potentials and temperatures in the presence of nitrites ions in aqueous solution, and to determine the limit of detection of $\mathrm{NO}_{2}^{-}$using $\mathrm{CPE} / \mathrm{Ru}(\mathrm{III})$-BSAP-PLA electrode, respectively. The main objective of the present work was to compare the efficiency of CPE/Ru(III)-BSAP-PLA sensor towards $\mathrm{NO}_{2}^{-}$ with the previously developed sensor using modified cavity microelectrode [54].

\section{Materials and methods}

\subsection{Apparatus and reagents}

Scanning electron microscopy analysis coupled with energy dispersive spectroscopy (SEM-EDS) were carried out using a scanning electronic microscope FEI QUANTA 250 (American company).

The potentiodynamic polarization studies were performed using a Potentiostat/Galvanostat Radiometer PGP 201 (Denmark) controlled with Voltamaster 4 software. Polarization curves were recorded at a scan rate of $1 \mathrm{mV} \mathrm{s}^{-1}$ by using a three electrochemical cell: Platinum wire and saturated calomel electrode (SCE) as auxiliary and reference electrode, respectively; copper disk electrode (surface area: $3.14 \mathrm{~cm}^{2}$ ) as the working electrode. The aggressive solution used in this part was sodium chloride solution (3\%).

Electrochemical measurements (Electrochemical Impedance Spectroscopy and Cyclic Valtammetry) were performed under a nitrogen atmosphere using Metrohm PGSTAT 302N (Metrohm Autolab, the Netherlands) with ECD and FRA module with an electrochemical cell constituted by an unmodified or modified carbon paste electrode, glassy carbon (GC) and $\mathrm{Ag} / \mathrm{AgCl}\left(3 \mathrm{~mol} \mathrm{~L}^{-1} \mathrm{KCl}\right)$ as working electrode, counter electrode and reference electrode, respectively.

The electrochemical impedance spectroscopy technique was conducted after maintaining the working electrode at its open circuit potential for $20 \mathrm{~min}$.

Before each measurement, the electrodes were polished with silicon carbide abrasive papers and immediately transferred into the test solution. 
A Fisher Scientific Polystat 36 (Fisher scientific, Switzerland) water bath equipped with a thermostat was used to maintain the fixed temperature for all experiments.

pH measurements were performed with A Metrohm 827 pH Lab Meter (Metrohm, the Netherlands) . A Precia Labo analytical balance model BP 110 S was used to weigh the products.

All reagents used in this work were of the highest purity and analytical grade from Merck (Germany) or Fluka (Switzerland). The ruthenium and nitrite solutions were prepared from stock solutions $\left(0.1 \mathrm{~mol} \mathrm{~L}^{-1}\right)$ of pure ruthenium(III) chloride and sodium nitrite salts in deionised water (resistivity $\geq 14 \mathrm{M} \Omega \mathrm{cm}$ ).

\subsection{Synthesis of the complex}

$\mathrm{Ru}(\mathrm{III})$-BSAP-PLA complex was synthesized through the reaction of 1,3-bis (2-hydroxysalicylideneamino) propan-2-ol, 3-picolylamine and Ru(III) chloride hydrate in acetone [54]. The formed dark precipitate was then collected and wached with deionized water. (Yield 70\%, 0.652 g, m.p. $>300^{\circ} \mathrm{C}$ ).

\section{3. Preparation of the modified electrode}

The modified carbon paste electrode was prepared by addition of a few drops of paraffin oil to the product resulting from mixing $10 \mathrm{mg}$ of $\mathrm{Ru}(\mathrm{III})$-BSAP-PLA powder with $300 \mathrm{mg}$ of graphite. The obtained compound was well mixed to obtain a smooth paste.

The modified electrodes were prepared by packing the modified paste into a glass tube having a diameter of 3 $\mathrm{mm}$. The electrical contact was ensured by a wire of copper.

\subsection{Electrochemical impedance spectroscopy}

EIS is a sensitive method used to study the interface properties between electrode and solution [55-57].

The impedance spectra were recorded in the frequency range $0.1 \mathrm{~Hz}-10 \mathrm{kHz}$ by using a sinusoidal excitation signal (single sine) with excitation amplitude of $0.01 \mathrm{~V}$.

The electrochemical parameters representing the unmodified and modified electrode-electrolyte configuration were evaluated from equivalent electric circuits by using the ZView program.

The constant phase element $(C P E)$ was modelled as a non-ideal capacitor, it can be expressed by the following equation [58]:

$$
C P E=\frac{-1}{(C i \omega)^{n}}
$$


where $C$ is a constant (describes the charge separation at the double layer interface), $i$ is the imaginary number, $\omega$ is the angular frequency $\left(\operatorname{rad~s}^{-1}\right)$ and $n$ exponent is due to the heterogeneity of the surface $(0<n<1)$.

The Warburg impedance was modelled as an open circuit finite Warburg element which includes a diffusion resistance, and was determined by the following equation:

$$
Z_{W}=\frac{(1-j) \sigma}{(\omega)^{\frac{1}{2}}}
$$

where $Z_{w}$ is the impedance of Warburg, $\sigma$ present the coefficient of Warburg $\left(\Omega \mathrm{s}^{-1 / 2}\right), \omega$ is the angular frequency and $j$ is a constant.

To simulate the electrochemical behaviour, an equivalent circuit was proposed as a model to determine the different parameters such as $R_{S}$ (solution resistance), $R_{1}\left(R_{C t}\right)$ (charge transfer resistance) and $C P E_{1}$ (double layer capacitance). $R_{2}$ and $Z_{w}$ are the parameters related to the mass transport $[59,60]$.

\section{Results and discussion}

\subsection{SEM-EDS characterization of the modified electrode}

The morphology, particle size and microchemical analysis of the surface of the modified electrode were studied by SEM-EDS technique (Fig. 1). The SEM photographs showed an uniform surface formed with the different compounds of the modified electrode (graphite, paraffin oil and $\mathrm{Ru}(\mathrm{III})$ complex). $\mathrm{Ru}(\mathrm{III})$ complex was homogeneously distributed on the graphite in the presence of paraffin oil as binder. EDS analysis (not shown here) of the surface of the modified paste electrode shows that the Ru (3.23\%), carbon (51.12\%) and oxygen $(10.76 \%)$ elements were detected with a significant concentrations.

\subsection{Polarization study}

Before studying the electro-catalytic oxidation of $\mathrm{NO}_{2}{ }^{-}$on modified carbon paste electrode, it is very interesting to evaluate, in an aggressive solution, the behavior of the conductive wire (copper) in the presence of the mixed Ru(III)-BSAP-PLA complex in the carbon paste. For this, the polarization method was used.

The anodic and cathodic polarization curves, recorded on the copper electrode, in the absence and presence of $\mathrm{Ru}(\mathrm{III})$ complex are shown in figure 2.

In the presence of the complex at $10^{-4}$ and $10^{-3} \mathrm{~mol} \mathrm{~L}^{-1}$, remarkable changes were observed on the polarization curves. In the anodic potential range (Fig. 1), the presence of ternary Ru(III) complex is characterized by the disappearance of the characteristic peak of copper $(\mathrm{Cu}(\mathrm{I}) / \mathrm{Cu}(\mathrm{II}))$ observed at $\mathrm{E}=68 \mathrm{mV}$.

The electrochemical parameters obtained from the polarization curves in $3 \% \mathrm{NaCl}$ are given in table 1 . 
Inhibition efficiency $(\mathrm{E} \%)$ is obtained from the following equation:

$$
E \%=\frac{i_{\text {corr }}(\text { blank })-i_{\text {corr }}(\text { inhib }) \times 100}{i_{\text {corr }}(\text { blank })}
$$

where $i_{\text {corr }}$ (inhib) and $i_{\text {corr }}$ (blank) are the corrosion current density values in the presence and absence of inhibitor (Ru(III)-BSAP-PLA), respectively.

Table 1 shows that the corrosion current density decreased considerably with increasing concentration of Ru(III) complex. The effect was maximal at $10^{-3} \mathrm{~mol} \mathrm{~L}^{-1}$ in which the inhibition efficiency attained $62.5 \%$.

In conclusion, by plotting the polarization curves from the material providing contact with the modified carbon paste, we verified that the presence of Ru(III)-BSAP-PLA complex in contact with the conductive wire (copper) did not affect the electrical contact.

\subsection{Electrochemical impedance spectroscopy characterizations of the modified electrode}

The electrochemical impedance spectroscopy technique was used to study the whole process in preparing modified electrodes, which could provide useful information on the changes of the surface of the modified electrodes [61].

In order to evaluate the nitrite oxidation process, $\mathrm{CPE} / \mathrm{Ru}(\mathrm{III})$-BSAP-PLA electrode was examined to determine the carbon paste/Ru(III) complex system's charge carrier capacity and the transfer properties.

The unmodified and modified electrode with $\mathrm{Ru}(\mathrm{III})$-BSAP-PLA complex were characterised by EIS method. Measurements were performed in $0.1 \mathrm{~mol} \mathrm{~L} \mathrm{~L}^{-1}$ phosphate buffer $\left(\mathrm{Na}_{2} \mathrm{HPO}_{4} / \mathrm{NaH}_{2} \mathrm{PO}_{4} ; \mathrm{pH}=7\right)$ at different potentials, and the modified electrode was tested at different temperatures.

\subsubsection{Potential effect}

In this part, EIS was employed to investigate the impedance changes of the surface of the carbon paste electrode after modification with $\mathrm{Ru}$ (III) complex at different reduction and oxidation potentials around OCP (cathodic potentials: $50 \mathrm{mV}$ to $-150 \mathrm{mV}$; anodic potentials: $50 \mathrm{mV}$ to $250 \mathrm{mV}$ ).

Fig. S1 (see supplementary material) shows EIS diagrams of the unmodified carbon paste electrode (CPE) in $\mathrm{Na}_{2} \mathrm{HPO}_{4} / \mathrm{NaH}_{2} \mathrm{PO}_{4}$ solution at different potentials (cathodic potentials: $180 \mathrm{mV}$ to $-20 \mathrm{mV}$; anodic potentials: $180 \mathrm{mV}$ to $380 \mathrm{mV}$ ). The impedance plots present an almost linear correlation of Z" (imaginary impedance) and Z' (real impedance) at lower frequency, indicating a diffusion process. This phenomenon corresponds to the Warburg impedance which reflects no electron transfer occurring at these potentials. 
The shape of the curves does not change with increasing or decreasing the applied potential. The Bode diagrams show one time constant for all applied potentials, thus, confirming the pure diffusion process through the electrode-solution interface. However, this phenomenon was not observed on the surface of the carbon paste electrode modified with $\mathrm{Ru}$ (III) complex (Fig. S2). The electrochemical parameters deducted from EIS are illustrated in table 2 .

According to these results, the presence of our complex on the CPE surface, leads to a significant decrease in the resistance of charge transfer with higher applied oxidation and reduction potentials (Table 2). The associated capacitance $\left(C P E_{1}\right)$ remained constant with low values, indicating the presence of very low quantities of the electro-active species accumulating at the electrode-solution interface. On the other hand, $n$ remain constant for all applied potentials, suggesting that the electro activity of the surface of the unmodified and modified electrodes does not depend on the applied potential. Values of $n$ are around 0.7 at the unmodified electrode and 0.4 at the modified electrode, suggesting that CPE/Ru(III)-BSAP-PLA electrode may have less smoother and less uniform surface than the unmodified electrode.

\subsubsection{Potential effect with nitrite ions in solution}

Direct information about the capacity of electron transfer across the different electrodes and electrolyte interface can be obtained by EIS in the presence of nitrite ions in solution. Impedance spectra recorded at different oxidation potentials using unmodified and modified electrodes in $\mathrm{Na}_{2} \mathrm{HPO}_{4} / \mathrm{NAH}_{2} \mathrm{PO}_{4}$ solution containing 0.01 mol L-1 $\mathrm{NO}_{2}^{-}$are shown in figures $\mathrm{S} 3$ and 3, respectively.

The electrochemical impedance diagrams obtained with carbon paste electrode (Fig. S3) shows the presence of a single capacitive semi-circle, relating to the charge transfer resistance at the surface of carbon paste electrode, and the absence of the diffusionnelle semi-circle.

The generic electrical circuit consists of a cell resistance $\left(R_{s}\right)$ in parallel with a constant phase element $\left(C P E_{l}\right)$, connected all in series with a charge transfer resistance $\left(R_{1}\right)$ (Fig. 4a).

During the next step, after the modification of the electrode with Ru(III)-BSAP-PLA complex, the recorded EIS shape differs from that of the carbon paste electrode.

The impedance plots performed using CPE/Ru(III)-BSAP-PLA electrode (Fig. 3) shows the presence of two semi-circles. The first (high frequencies zone) with the diameter being independent of the electrode potential, which is related to the charge transfer resistance at the carbon paste electrode modified with Ru(III)-BSAP-PLA, which suggests that nitrite ions were successfully immobilized on the surface of the modified electrode. 
The first semi-circle is flatter than the second. This phenomenon is a characteristic of the surface roughness of the electrode (deviation from ideal behaviour) [62, 63]. The second semi-circle (low frequency zone) corresponds to the phenomenon of diffusion. The imaginary impedance value was higher at anodic potential $\mathrm{E}_{\mathrm{a}}=0.09 \mathrm{~V}$, indicating easier charge separation at this potential value.

The comparison between Fig. 3Sa and Fig. 3a at high frequencies zone showed that a semi-circle with a large diameter is observed with carbon paste electrode. However, this diameter is significantly reduced with $\mathrm{CPE} / \mathrm{Ru}(\mathrm{III})-\mathrm{BSAP}-\mathrm{PLA}$ electrode, suggesting that the surface of the modified electrode exhibited lower electron transfer resistance (Table 3).

By examining the different Bode diagrams $(\log |Z|$ and phase shift (f) versus log (f), we observed two time constants, confirming the nature of the mechanism observed in Fig. $3 \mathrm{a}$.

EIS data were fitted with equivalent electrical circuit (Fig. 4b). Good agreements between the experimental and calculated parameters were obtained from the best fitting equivalent circuit model, where the chi-squared $\left(\chi^{2}\right)$ minimized between $10^{-4}$ and $10^{-3} \cdot \chi^{2}$ is the function defined as the sum of the squares of the residuals.

The estimated electrical circuit used to model the Nyquist spectra consists of a cell resistance $\left(R_{s}\right)$, constant phase element $\left(C P E_{1}\right)$ connected in series with a parallel combination of a charge transfer resistance $\left(R_{1}\right)$ and $C P E_{2}$ (representing modified electrode-solution interface), which was in series with a resistance $R_{2}$.

The electrochemical impedance parameters are summarized in table 3. By analyzing the EIS data at different potentials, it can be obseryed that the highest value of the charge transfer resistance $\left(\mathrm{R}_{1}\right)$ is obtained at $-0.110 \mathrm{~V}$, and $\mathrm{R}_{1}$ decreased with the applied anodic potential.

The results reported in table 3 reveals that $R_{2}$ increases with increasing anodic potentials, indicating that the barrier effect of the surface of the electrode is characterized by Warburg impedance (form of a capacitive semicircle).

In the presence of nitrite in solution, the charge transfer resistance of our modified electrode (CPE/Ru(III)BSAP-PLA) was lower than $R_{1}$ of the unmodified electrode. The decrease of charge transfer resistance concerning the adsorption of nitrite on the modified electrode is due to the morphology and surface porosity of the carbon paste/Ru(III)-BSAP-PLA product, the latter may be attributed to the electrostatic interaction between the nitrite ions (negatively charged $\mathrm{NO}_{2}^{-}$) and $\mathrm{Ru}(\mathrm{III})$-BSAP-PLA complex. At anodic potentials, the values of $C P E_{1}$, determined using the modified electrode, are higher than those determined using the unmodified electrode, primarily due to an increase in the charge accumulated on the surface of CPE/Ru(III)-BSAP-PLA 
electrode. The presence of our complex in the modified electrode significantly increased the capacity values. This result indicated that the electron transfer has been facilitated in the presence of our modified electrode.

The values of $n_{1}$ are less than 1 , which resulted in CPE impedance behaviour. In fact, these values remained practically unchanged with increasing the applied potential, indicating that the surface of the electrode remains stable. The estimated $n_{1}$ values may be due to the distribution of activation energies in the double-layer, as well as to the roughness and the unhomogeneity of the surface of the electrode [64].

\subsubsection{Temperature effect in the presence of $\mathrm{NO}_{2}^{-}$in solution}

To characterize the mode of transportation of the material and the sensitivity of our sensor in aqueous solution, the electrochemical impedance diagrams have been plotted at different temperatures. The measurements were carried out in $\mathrm{Na}_{2} \mathrm{HPO}_{4} / \mathrm{NaH}_{2} \mathrm{PO}_{4}\left(0.1 \mathrm{~mol} \mathrm{~L}{ }^{-1}\right)$ at $\mathrm{pH}=7$.

Electrochemical impedance spectroscopy is an extremely powerful and sensitive characterisation technique to probe the charge transfer and charge separation processes occurring at electrode-solution or modified electrodesolution interfaces; the effect of temperature can also be studied using the same technology $[59,65]$.

The impedance diagrams of the modified electrode, recorded at $0.9 \mathrm{~V}$, are illustrated in Fig. 5.

The Nyquist plot exhibits two capacitive semi-circles: the first located at high frequencies, which corresponds to the electron transfer process, while the second, observed at lower frequencies, represent the diffusion control.

We observe that the increase of temperature does not change the shape of Nyquist diagram. Bode diagrams showed the presence of two time constants for all temperatures, confirming the pure mode of activation and diffusion. The EIS parameters are given in table 4 . The obtained results reveal that $\mathrm{R}_{1}$ decreases with increasing temperature value. On the other hand, the double-layer capacitance increases with increasing temperature, this is due to the accumulation of nitrite in the surface of the modified electrode, which increases the active surface area of the electrode [55].

3.4. Electrochemical behaviour of the modified electrode towards nitrite ions by using cyclic voltammetry method

\subsubsection{Effect of varying scan rate on the electro-oxidation of nitrite ions}

The transport characteristics of the modified electrode were investigated at different scan rates in $0.1 \mathrm{~mol} \mathrm{~L}^{-1}$ buffer phosphate solution containing $1.38 \times 10^{-2} \mathrm{~mol} \mathrm{~L}^{-1} \mathrm{NO}_{2}{ }^{-}$. Figure 6a showed that the current of the oxidation peak increases with increasing scan rates. Two linear regression equations between the oxidation current and the 
square root of scan rate in the range $10-60 \mathrm{mV} \mathrm{s}^{-1}\left(i=47.77 v^{\frac{1}{2}}+25.95 ; R^{2}=0.998\right)$ and $60-80 \mathrm{mV} \mathrm{s}^{-1}$ $\left(i=144.77 v^{\frac{1}{2}}-728.84 ; R^{2}=0.994\right)$ were obtained (Fig. 6b). This result reveals that the kinetic of the overall process is controlled by diffusion and adsorption.

Figure $6 \mathrm{c}$ showed that the oxidation potential increases linearly with increasing the scan rate, such variation follows the linear equation $E_{p a}=125.167 \log v+902.873 \quad\left(R^{2}=0.995\right)$. The linearity confirms the irreversible electro oxidation process of nitrite. By referring to the Tafel equation, defining a totally irreversible electrochemical process [66], and assuming that the oxidation of nitrite involves the transfer of two electrons, the electron transfer coefficient determined was $\alpha=0.89$. A comparison between this value and that found in a previous study $(\alpha=0.83)$, using the modified cavity microelectrode [54], reveals that the electro-catalytic mechanism of oxidation of nitrite occurs better on the surface of our carbon paste electrode modified with $\mathrm{Ru}(\mathrm{III})$ complex.

\subsubsection{Effect of solution $p H$}

The electrochemical behavior of CPE/Ru(III)-BSAP-PLA electrode in the presence of nitrite ions in solution was studied at various $\mathrm{pH}$ values, results are reported in figure 7.

The current increases over a range of $\mathrm{pH}$ values from 2 to 4.12 , and the maximum current is located at $\mathrm{pH}=4.12$. For $\mathrm{pH}$ values higher than 4.12 and up to 8.05 , the oxidation current was found to decrease throughout the range. In the acidic medium ( $\mathrm{pH}=2$ to 4.12$), \mathrm{Ru}(\mathrm{III})$-BSAP-PLA is positively charged on the surface of the carbon paste electrode which can attract the negatively charged nitrite ions, thus, inducing a better electro catalytic oxidation of the nitrite ions. By comparing our result with previous studies [54], within the same $\mathrm{pH}$ range (2 to 4.12), we find that the current of the oxidation peak of nitrite increases at the surface of CPE/Ru(III)-BSAP-PLA electrode and decreases at the modified cavity microelectrode.

\subsection{Detection of nitrite ions using modified electrode}

The use of amperometric methods in the field of electro-analysis represents an important alternative for the detection of various pollutant species. The aim of this study is to determine the limit of detection (LOD) of nitrite ions in aqueous solution using $\mathrm{CPE} / \mathrm{Ru}(\mathrm{III})$-BSAP-PLA modified electrode. LOD is defined as the low concentration value which generates an electrical signal (faradic current intensity) at least greater to three times the amplitude of the background residual current [67]. 
In this part, the voltammograms were recorded in a buffer phosphate solution at room temperature, in the potential range from 0 to $1.4 \mathrm{~V}$ at a scan rate of $0.020 \mathrm{~V} \mathrm{~s}^{-1}$. The electrochemical study was focused on anodic oxidation of $\mathrm{NO}_{2}{ }^{-}$over the concentration range $0-1.38 \times 10^{-2} \mathrm{~mol} \mathrm{~L}^{-1}$. To evaluate the limit of detection of nitrite ions (LOD) using CPE/Ru-BSAP-PLA electrode, the calibration plot of the oxidation current versus concentration of $\mathrm{NO}_{2}^{-}$was reported; the linear equation is as follows:

$$
i=a \times\left[\mathrm{NO}_{2}^{-}\right]+b
$$

The limit of detection of $\mathrm{NO}_{2}{ }^{-}$is determined according to the following equation [68-70]:

$$
L O D=\frac{3 s}{a}
$$

Where $s$ is the standard deviation of the blank signal and $a$ is the slope of the calibration plot.

To determine the influence of concentration on the nitrite oxidation response at the modified electrode, cyclic voltammograms were recorded at different concentrations of $\mathrm{NO}_{2}^{-}$. Figure 8a indicates that the modified carbon paste electrode (CPE/Ru(III)-BSAP-PLA) showed no faradic current response in the absence of nitrite ions in the test sample. However, the addition of $\mathrm{NO}_{2}{ }^{-}$reveals the appearance of an oxidation peak around $0.90 \mathrm{~V}$, which is becoming more intense with increasing concentration of $\mathrm{NO}_{2}^{-}$.

The catalytic reaction mechanism that is compatible with our recorded voltammograms is given in the following reactions:

$$
\begin{aligned}
& 2\left(R u^{I I I} \text { complex }\right) \leftrightarrow 2\left(R u^{I V} \text { complex }\right)^{+}+2 e^{-}
\end{aligned}
$$

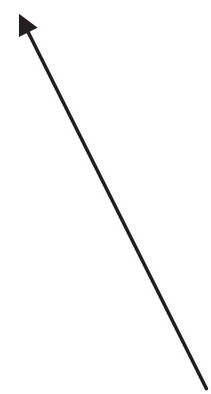

$$
\begin{aligned}
& \uparrow+2 N O- \\
& 2 \\
& \text { 2( } \left.\mathrm{Ru}^{\mathrm{III}} \text { complex }-\mathrm{NO}_{2}\right) \\
& \uparrow \\
& 2\left(\mathrm{Ru}^{\mathrm{III}} \text { complex }\right)+2 \mathrm{NO}_{2}+2 e^{-} \\
& \uparrow+\mathrm{H}_{2} \mathrm{O} \\
& \mathrm{NO}_{2}{ }^{-}+\mathrm{NO}_{3}{ }^{-}+2 \mathrm{H}^{+}
\end{aligned}
$$


The intermediate compound $\left(\mathrm{Ru}^{\mathrm{III}}\right.$ complex $\left.-\mathrm{NO}_{2}\right)$, corresponding to the electronic coupling between $\mathrm{Ru}^{4+}$ in $\left(\mathrm{Ru}^{\mathrm{IV}} \text { complex }\right)^{+}$and $\mathrm{NO}_{2}^{-}$, was suggested as the nitrite activation step to regenerate $\mathrm{Ru}^{\mathrm{III}}$ complex and to form $\mathrm{NO}_{2}$, which is the converted to $\mathrm{NO}_{2}{ }^{-}$and $\mathrm{NO}_{3}{ }^{-}[71]$.

The overall chemical reaction is shown as follows:

$$
2\left(\mathrm{Ru}^{\mathrm{IV}} \text { complex }\right)^{+}+\mathrm{NO}_{2}{ }^{-}+\mathrm{H}_{2} \mathrm{O} \leftrightarrow \mathrm{NO}_{3}{ }^{-}+2 \mathrm{H}^{+}+2 \mathrm{Ru}^{\mathrm{III}} \text { complex }
$$

The calibration plot (Fig. 8b) showed a good linear relationship $\left(i=17306.50\left[\mathrm{NO}_{2}^{-}\right]-0.13\right)$ between the oxidation current and nitrite concentration, with correlation coefficient $\mathrm{R}^{2}=0.998$, found over a wide concentration range $0-1.38 \times 10^{-2} \mathrm{~mol} \mathrm{~L}^{-1}$.

The sensitivity of the carbon paste electrode, modified with $\mathrm{Ru}(\mathrm{III})$-BSAP-PLA complex, is $17.31 \times 10^{-3} \mathrm{~A}(\mathrm{~mol}$ $\left.\mathrm{L}^{-1}\right)^{-1}$. The LOD, determined using CPE/Ru(III)-BSAP-PLA electrode $\left(1.39 \times 10^{-6} \mathrm{~mol} \mathrm{~L}^{-1}\right)$, is lower than that

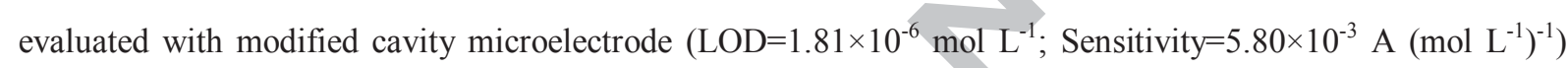
$[46]$.

In comparing the results obtained using CPE/Ru(III)-BSAP-PLA electrode with those found using $\mathrm{CME} / \mathrm{G} / \mathrm{Ru}(\mathrm{III})-\mathrm{BSAP}-\mathrm{PLA}$ electrode [54], under the same conditions, it is important to note that LOD calculated in this work were covered throughout a wider range of concentration values $\left(0-1.38 \times 10^{-2} \mathrm{~mol} \mathrm{~L}^{-1}\right)$ than that used in previous work $\left(0-1.59 \times 10^{-4} \mathrm{~mol} \mathrm{~L}^{-1}\right)$.

\section{Conclusion}

The objective of the present work is to develop an amperometric sensor based on carbon paste electrode modified with ternary $\mathrm{Ru}(\mathrm{III})$ complex for the determination of nitrite ions $\left(\mathrm{NO}_{2}{ }^{-}\right)$in aqueous solution.

EIS measurements showed that the presence of $\mathrm{Ru}(\mathrm{III})$ complex on the surface of the modified carbon paste electrode significantly decreases the charge transfer resistance $\left(R_{1}\right)$ with increasing potentials and temperature. Whereas, $C P E_{1}$ increases with increasing temperature, indicating the accumulation of $\mathrm{NO}_{2}{ }^{-}$on the surface of the modified electrode, which increases the active surface area of the modified electrode.

The electron transfer coefficient, determined using cyclic voltammetry $(\alpha=0.89)$, revealed that the mechanism of electro-catalytic oxidation of $\mathrm{NO}_{2}^{-}$takes place on the surface of the carbon paste electrode modified with the $\mathrm{Ru}(\mathrm{III})$ complex.

By comparing this work with that previously performed, the lower limit of detection of nitrite ions, calculated using CPE/Ru(III)-BSAP-PLA electrode, is more important than that found with modified cavity microelectrode 
$(\mathrm{CME} / \mathrm{G} / \mathrm{Ru}(\mathrm{III})-\mathrm{BSAP}-\mathrm{PLA})$ because the used concentration range of $\mathrm{NO}_{2}^{-}$is very wider $\left(0-1.38 \times 10^{-2} \mathrm{~mol} \mathrm{~L}^{-1}\right)$ than that used in previous study $\left(0-1.59 \times 10^{-4} \mathrm{~mol} \mathrm{~L}^{-1}\right)$.

\section{Acknowledgments}

The authors would like to acknowledge the MESRS Algerian Ministry and Directorate-General for Scientific Research and Technological Development (Algeria) for supporting the present research.

\section{References}

[1] A. Arecchi, M. Scampicchio, S. Drusch, S. Mannino, Nanofibrous membrane based tyrosinase-biosensor for the detection of phenolic compounds, Anal Chim Acta 659 (2010) 133-136. doi:10.1016/j.aca.2009.11.039

[2] K. Krishnamurthi, S.S. Devi, T. Chakrabarti, DNA damage caused by pesticide contaminated soil, Biomed. Environ. Sci. 19 (2006) 427-431.

[3] G. Griffo, L. Piper, A. Lay-Ekuakille, D. Pellicanò, Design of buoy station for marine pollutant detection, Measurement 47 (2014) 1024-1029. doi:10.1016/j.measurement.2013.09.039

[4] A. Farahi, L. El Gaini, M. Achak, S. El Yamani, M.A. El Mhammedi, M. Bakasse, Interaction study of paraquat and silver electrode using electrochemical impedance spectroscopy: Application in milk and tomato samples, Food Control. 47 (2015) 679-685. doi:10.1016/j.foodcont.2014.08.005

[5] P. Kumar, S. Saravanan, K. Ranjith, P.C. Ramamurthy, D-A-D-structured conducting polymer-modified electrodes for detection of lead(II) ions in water Prajwal, J. Appl. Electrochem. 44 (2014) 133-139. doi:10.1007/ s10800-013-0615-5

[6] M.H. Pournaghi-Azar, H. Dastangoo, Electrocatalytic oxidation of nitrite at an luminium electrode modified by a chemically deposited palladium pentacya-nonitrosylferrate film, J. Electroanal. Chem. 567 (2004) 211-218. doi:10.1016/j.jelechem.2003.12.027

[7] C. Ait-Ramdane-Terbouche, A. Terbouche, S. Djebbar, D. Hauchard, Electrochemical sensors using modified electrodes based on copper complexes formed with Algerian humic acid modified with ethylenediamine or triéthylènetetramine for determination of nitrite in water, Talanta 119 (2014) 214-225. doi.org/10.1016/j.talanta.2013.10.049

[8] C. Shinn, A. Marco, L. Serrano, Influence of low levels of water salinity on toxicity of nitrite to anuran larvae, Chemosphere 92 (2013) 1154-1160. doi: 10.1016/j.chemosphere.2013.01.079 
[9] A. Terbouche, C. Ait-Ramdane-Terbouche, S. Djebbar, O. Benali-Baitich, D. Hauchard, Effectiveness study of sensor based on modified cavity microelectrode by Algerian humic acid-polyaniline composites using square wave voltammetry, Sens. Actuators B 169 (2012) 297-304. doi.org/10.1016/j.snb.2012.04.085

[10] N.N. Zhu, Q. Xu, S. Li, H. Gao, Electrochemical determination of nitrite based on poly(amidoamine) dendrimer-modified carbon nanotubes for nitrite oxidation, Electrochem. Commun. 11 (2009) 2308-2311. doi:10.1016/j.elecom.2009.10.018

[11] H. Dong, Z. Fang, T. Yang, Y. Yu, D. Wang, K-C. Chou, X. Hou, Single crystalline 3C-SiC whiskers used for electrochemical detection of nitrite under neutral condition, Ionics (2016) 1-8. doi: 10.1007/s11581016-1666-5

[12] M. Guo, J. Chen, J. Li, B. Tao, S. Yao, Fabrication of polyaniline/carbon nanotubes composite modified electrode and its electrocatalytic property to the reduction of nitrite, Anal. Chim. Acta 532 (2005)71-77. doi:10.1016/j.aca.2004.10.045

[13] Y. Tian, J. Wang, Z. Wang, S. Wang, Electroreduction of nitrite at an electrode modified with polypyrrole nanowires, Synth. Met. 143 (2004) 309-313. doi:10.1016/j.synthmet.2003.12.014

[14] S. Kakhki, E. Shams, M.M. Barsan, A new bifunctional electrochemical sensor for oxidation of cysteine and reduction of iodate, J. Electroanal. Chem. 704 (2013) 80-85. doi:10.1016/j.jelechem.2013.01.017

[15] A.S. Adekunle, J. Pillay, K.I. Ozoemena, Probing the electrochemical behaviour of SWCNT-cobalt nanoparticles and their electrocatalytic activities towards the detection of nitrite at acidic and physiological $\mathrm{pH}$ conditions, Electrochim. Acta 55 (2010) 4319-4327. doi:10.1016/j.electacta.2009.02.102

[16] C.Y. Lin, V.S. Vasantha, K.C. Ho, Detection of nitrite using poly(3,4-ethylenedioxythiophene) modified SPCEs, Sens. Actuators B 140 (2009) 51-57. doi: 10.1016/j.snb.2009.04.047

[17] T.S. Liu, T.F. Kang, L.P. Lu, Y. Zhang, S.Y. Cheng, Au-Fe(III) nanoparticle modified glassy carbon electrode for electrochemical nitrite sensor, J. Electroanal. Chem. $632 \quad$ (2009) 197-200. doi:10.1016/j.jelechem.2009.04.023

[18] Q.P. Chen, S.Y. Ai, X.B. Zhu, H.S. Yin, Q. Ma, Y.Y. Qiu, A nitrite biosensor based on the immobilization of Cytochrome c on multi-walled carbon nanotubes-PAMAM-chitosan nanocomposite modified glass carbon electrode, Biosens. Bioelectron. 24 (2009) 2991-2996. doi:10.1016/j.bios.2009.03.007 
[19] M.A. Kamyabi, F. Aghajanloo, Electrocatalytic oxidation and determination of nitrite on carbon paste electrode modified with oxovanadium(IV)-4-methyl salophen, J. Electroanal. Chem. 614 (2008) 157-165. doi:10.1016/j.jelechem.2007.11.026

[20] F. Xiao, L.Q. Liu, J. Li, J. Zeng, B. Zeng, Electrocatalytic Oxidation and Voltammetric Determination of Nitrite on Hydrophobic Ionic Liquid-Carbon Nanotube Gel-Chitosan Composite Modified Electrodes, Electroanalysis 20 (2008) 2047-2054. doi: 10.1002/elan.200804288

[21] E.H. Seymour, N.S. Lawrence, M. Pandurangappa, R.G. Compton, Indirect Electrochemical Detection of Nitrite via Diazotization of Aromatic Amines, Microchim. Acta 140 (2002) 211-217. doi:10.1007/s00604-0020915-7

[22] L.H. Larsen, L.R. Damgaard, T. Kjaer, T. Stenstrom, A. Lynggard-Jensen, P. Revsbech, Fast responding biosensor for on-line determination of nitrate/nitrite in activated sludge, Water Res. 34 (2000) 2463-2468. doi:10.1016/S0043-1354(99)00423-6

[23] H. Gunasingham, C.B. Tan, Platinum-dispersed Nafion film modified glassy carbon as an electrocatalytic surface for an amperometric glucose enzyme electrode, Analyst 114 (1989) 695-698. doi: 10.1039/AN9891400695

[24] F.L. Leite, A. Firmino, C.E. Borato, L.H.C. Mattoso, W.T.L. Da Silva, O.N. Oliveira, Sensor arrays to detect humic substances and $\mathrm{Cu}(\mathrm{II})$ in waters, Synth. Metals 159 (2009) 2333-2337. doi:10.1016/j.synthmet.2009.07.058

[25] A. Salimi, B. Kavosi, A. Babaei, R. Hallaj, Electrosorption of Os(III)-complex at single-wall carbon nanotubes immobilized on a glassy carbon electrode: Application to nanomolar detection of bromate, periodate and iodate, Anal. Chim. Acta 618 (2008) 43-53. doi: 10.1016/j.aca.2008.04.047

[26] J.R. Steter, J.O.S. Ponto' lio, M.I.C.F. Costa, J.R. Romero, A new polyphenol modified electrode containing an anchored ruthenium complex and its use in electrocatalytic oxidation of organic substrates, Polyhedron 26 (2007) 996-1000. doi:10.1016/j.poly.2006.09.039

[27] A.R. Zanganeh, M.K. Amini, Polypyrrole-modified electrodes with induced recognition sites for potentiometric and voltammetric detection of copper(II) ion, Sens. Actuators B 135 (2008) 358-365. doi:10.1016/j.snb.2008.09.005

[28] D. Kriz, O. Ramstrom, K. Mosbach, Molecular imprinting: new possibilities for sensor technology, Anal. Chem. 69 (1997) 345-349. doi: 10.1021/ac971657e 
[29] G. Paimard, M.B. Gholivand, M. Shamsipur, Determination of ganciclovir as an antiviral drug and its interaction with DNA at $\mathrm{Fe}_{3} \mathrm{O}_{4}$ /carboxylated multi-walled carbon nanotubes modified glassy carbon electrode, Measurement 77 (2016) 269-277. doi:10.1016/j.measurement.2015.09.019

[30] A. Arvinte, A.C. Westermann, A.M. Sesay, V. Virtanen, Electrocatalytic oxidation and determination of insulin at CNT-nickel-cobalt oxide modified electrode, Sens. Actuators B 150 (2010) 756-763. doi:10.1016/j.snb.2010.08.004

[31] X. Ke, Z. Li, L. Gan, J. Zhao, G. Cui, W. Kellogg, D. Matera, D. Higgins, G. Wu, Three-dimensional nanoporous $\mathrm{Au}$ films as high-efficiency enzyme-free electrochemical sensors, Electrochim. Acta 170 (2015) 337-342. doi:10.1016/j.electacta.2015.04.144

[32] R. Zhang, S. Liu, L. Wang, G. Yang, Electroanalysis of ascorbic acid using poly(bromocresol purple) film modified glassy carbon electrode, Measurement $46 \quad$ (2013) 1089-1093. doi:10.1016/j.measurement.2012.11.007

[33] H. Beitollahi, S. Tajik, P. Biparva,Electrochemical determination of sulfite and phenol using a carbon paste electrode modified with ionic liquids and graphene nanosheets: Application to determination of sulfite and phenol in real samples, Measurement 56 (2014) 170-177. doi:10.1016/j.measurement.2014.06.011

[34] A.S. Sarac, M. Ates, B. Kilic, Electrochemical Impedance Spectroscopic Study of Polyaniline on Platinum, Glassy Carbon and Carbon Fiber Microelectrodes, Int. J. Electrochem. Sci. 3 (2008) 777-786.

[35] J.E. Weber, P. Pillai, K. Ram, A. Kumar, S.R. Singh, Electrochemical impedance-based DNA sensor using a modified single walled carbon nanotube electrode, Mater. Sci. Eng. C 31 (2011) 821-825. doi:10.1016/j.msec.2010.12.009

[36] S. Kocak, B. Aslisen, Hydrazine oxidation at gold nanoparticles and poly(bromocresolpurple) carbon nanotube modified glassy carbon electrode, Sens. Actuators B $196 \quad$ (2014) 610-618. doi:10.1016/j.snb.2014.02.061

[37] M.E. Ghica, R.C. Carvalho, A. Amine, C.M.A. Brett, Glucose oxidase enzyme inhibition sensors for heavy metals at carbon film electrodes modified with cobalt or copper hexacyanoferrate, Sens. Actuators B 178 (2013) 270- 278. doi:10.1016/j.snb.2012.12.113

[38] M.E. Ghica, C.M.A. Brett, Poly (brilliant green) and poly (thionine) modified carbon nanotube coated carbon film electrodes for glucose and uric acid biosensors, Talanta 130 (2014) 198-206. doi: 10.1016/j.talanta.2014.06.068. 
[39] A. Ramanavicius, P. Genys, A. Ramanaviciene, Electrochemical Impedance Spectroscopy Based Evaluation of 1, 10-Phenanthroline-5,6-dione and Glucose Oxidase Modified Graphite Electrode, Electrochim. Acta 146 (2014) 659-665. doi:10.1016/j.electacta.2014.08.130

[40] F. Valentini, A. Amines, S. Olanducci, M.L. Terranova, G. Palleschi, Carbon Nanotube Purification: Preparation and Characterization of Carbon Nanotube Paste Electrodes, Anal. Chem. 75 (2003) 5413. doi: $10.1021 / \mathrm{ac} 0300237$

[41] H. Bagheri, A. Shirzadmehr, M. Rezaei, Determination of copper ions in foodstuff products with a newly modified potentiometric carbon paste electrode based on a novel nano-sensing layer, Ionics 22 (2016) 12411252. doi: $10.1007 / \mathrm{s} 11581-016-1646-9$

[42] H. Bagheri, A. Afkhami, H. Khoshsafar, M. Rezaei, S.J. Sabounchei, M. Sarlakifar, Simultaneous electrochemical sensing of thallium, lead and mercury using a novel ionic liquid/graphene modified electrode, Anal. Chim. Acta 870 (2015) 56-66. doi:10.1016/j.aca.2015.03.004

[43] H. Bagheri, A. Afkhami, A. Shirzadmehr, H. Khoshsafar, A new nano-composite modified carbon paste electrode as a high performance potentiometric sensor for nanomolar Tl(I) determination, J. Mol. Liquids 197 (2014) 52-57.doi:10.1016/j.molliq.2014.04.023

[44] H. Bagheri, H. Khoshsafar, S. Amidi, Y. Hosseinzadeh Ardakani, Fabrication of an electrochemical sensor based on magnetic multi-walled carbon nanotubes for the determination of ciprofloxacin, Anal. Methods 8 (2016) 3383-3390. doi: 10.1039/C5AY03410H

[45] H. Bagheri, S.M. Arab, H. Khoshsafar, A. Afkhami, A novel sensor for sensitive determination of atropine based on $\mathrm{Co}_{3} \mathrm{O}_{4}$-reduced graphene oxide modified carbon paste electrode, New J. Chem. 39 (2015) 3875-3881. doi:10.1039/C5NJ00133A

[46] H. Bagheri, R.P. Talemi, A. Afkhami, Gold nanoparticles deposited on fluorine-doped tin oxide surface as an effective platform for fabricating a highly sensitive and specific digoxin aptasensor, RSC Adv. 5 (2015) 58491-58498. doi: 10.1039/C5RA09402J

[47] H. Bagheri, A. Afkhami, P. Hashemi, M. Ghanei, Simultaneous and sensitive determination of melatonin and dopamine with $\mathrm{Fe}_{3} \mathrm{O}_{4}$ nanoparticle-decorated reduced graphene oxide modified electrode, RSC Adv. 5 (2015) 21659-21669. Doi:10.1039/C4RA16802J

[48] H. Bagheri, A. Afkhami, Y. Panahi, H. Khoshsafar, A. Shirzadmehr, Facile stripping voltammetric determination of haloperidol using a high performance magnetite/carbon nanotube paste electrode in pharmaceutical and biological samples, Mater. Sci. Eng C 37 (2014) 264-270. doi:10.1016/j.msec.2014.01.023 
[49] C.M.A. Brett, O.AM. Brett, Electrochemistry, Principles Methods and Applications, 11, Oxford University Press, Oxford, 1993.

[50] F.M. El-Cheikh, F.A. Rashwan, H.A. Mahmoud, M. El-Rouby, Electrochemical response of the two isomers conjugated acids, maleic and fumaric, on glassy carbon electrode modified with platinum nanoparticles, J. Appl. Electrochem. 1 (2010) 79-89. doi:10.1007/s10800-009-9983-2

[51] A. Bardea, F. Patolsky, A. Dagan, I. Willner, Sensing and Amplification of Oligonucleotide-DNA Interactions by Means of Impedance Spectroscopy: A Route to a Tay-Sachs Sensor, Chem. Commun. 1 (1999) 21-22. doi: 10.1039/A808319C

[52] H. Taira, K. Nakano, M. Maeda, M. Takagi, Electrode modification by Long-Chain, Dialkyl Disulfide Reagent Having Terminal Dinitrophenyl group and its application to impedimetric immunosensors, Anal. Sci. 9 (1993) 199-206. doi: 10.2116/analsci.9.199

[53] H.O. Finklea, D.A. Snider, J. Fedyk, E. Sabatani, Y. Gafni, I. Rubinstein, Characterization of octadecanethiol-coated gold electrodes as microarray electrodes by cyclic voltammetry and ac impedance spectroscopy, Langmuir 9 (1993) 3660-3667. doi:10.1021/la00036a050

[54] A. Terbouche, C. Ait-Ramdane-Terbouche, S. Djebbar, D. Guerniche, R. Bagtache, N.E.H. Bensiradj, A. Saal, D. Hauchard, A new ternary ruthenium(III) complex with 1,3-bis(salicylideneamino)propan-2-ol and 3picolylamine: Synthesis, characterization, density functional theory and preparation of electrochemical sensor for nitrite analysis, J. Mol. Struct. 1076 (2014) 501-511. doi:10.1016/j.molstruc.2014.08.013

[55] J.S. Daniels, N. Pourmand, Label-free impedance biosensors: Opportunities and challenges, Electroanalytical 19 (2007) 1239-1257. doi: 10.1002/elan.200603855

[56] R.E. Ionescu, N. Jaffrezic-Renault, L. Bouffier, C. Gondran, S. Cosnier, D.G. Pinacho, M.P. Marco, F.J. Sánchez-Baeza, T. Healy, C. Martelet, Impedimetric immunosensor for the specific label free detection of ciprofloxacin antibiotic, Biosens. Bioelectron. 23 (2007) 549-555. doi:10.1016/j.bios.2007.07.014

[57] S.J. Ding, B.W. Chang, C.C. Wu, M.F. Lai, H.C. Chang, Impedance spectral studies of self-assembly of alkanethiols with different chain lengths using different immobilization strategies on Au electrodes, Anal. Chim. Acta 554 (2005) 43-51. doi:10.1016/j.aca.2005.08.046

[58] R. Pauliukaite, M.E. Ghica, O. Fatibello-Filho, C.M.A. Brett, Electrochemical impedance studies of chitosan-modified electrodes for application in electrochemical sensors and biosensors, Electrochim. Acta 55 (2010) 6239-6247. doi:10.1016/j.electacta.2009.09.055 
[59] M.E. Orazem, B. Tribollet, Electrochemical Impedance Spectroscopy, Published by John Wiley \& Sons, Hoboken, New Jersey, 2008.

[60] P.R. Roberge, Handbook of corrosion Engineering, Mcgraw-Hill, New York, 2000.

[61] J.J. Feng, H.Y. Chen, Synergistic effect of zirconium phosphate and Au nanoparticles on direct electron transfer of haemoglobin on glassy carbon electrode, J. Electroanal. Chem. 585 (2005) 44-50. doi:10.1016/j.aca.2005.08.046

[62] M. Jingling, W. Jiuba, W. Zhai, Q. Li, In situ corrosion analysis of Al-Zn-In-Mg-Ti-Ce sacrificial anode alloy, Mat. Charact. 65 (2012) 86-92. doi:10.1016/j.matchar.2012.01.003

[63] C.H. Kim, S.I. Pyun, J.H. Kim, An Investigation of the capacitance dispersion on the fractal carbon electrode with edge and basal orientations, Electrochim. Acta 48 (2003) 3455-3463. doi:10.1016/S00134686(03)00464-X

[64] S. Manov, A.M. Lamazouère, L. Ariès, Electrochemical study of the corrosion behaviour of zinc treated with a new organic chelating inhibitor, Corros. Sci. 42 (2000) 1235-1248. doi:10.1016/S0010-938X(99)00132-8 [65] L. Kobotiatis, N. Pebere, P.G. Koutsoukos, Study of the electrochemical behaviour of the 7075 aluminum alloy in the presence of sodium oxalate, Corros. Sci. 41(1999) 941-957. doi:10.1016/s0010-938x(98)00164-4 [66] A.J. Bard, L.R. Faulkner, Electrochemical Methods: Fundamentals and Applications, second ed., John Wiley and Sons, Hoboken, New Jersey, 2001.

[67] P. Fabry, J.C. Moutet, Sensitivity and selectivity of electrochemical sensors in chemical and biological microsensors. Fabry F, Fouletier J, Lavoisier, Paris, 2003. doi: 10.1002/9781118603871.ch3

[68] M. Sadikoglu, G. Saglikoglu, S. Yagmur, E. Orta, S. Yilmaz, Voltammetric determination of acyclovir in human urine using ultra trace grapite and glassy carbone electrodes, Current Anal. Chem. 7 (2011) 130-135. doi: $10.2174 / 157341111794815011$

[69] M. Çıtak, S. Yılmaz, Y. Dilgin, G. Türker, S. Yagmur, H. Erdugan, N. Erdugan, Osteryoung square xave voltammetry determination of phenazopyridine hydrochloride in human urine and tablet dosage forms based on electrochemical reduction at carbone paste electrode, Current Pharm. Anal. 3 (2007) 141-145. doi: $10.2174 / 157341207780598977$

[70] S. Yilmaz, B. Uslu, S.A. Ozkan, Anodic oxidation of etodolac and its square wave and differential pulse voltammetric determination in pharmaceuticals and human serum, Talanta 54 (2001) 351-360. doi:10.1016/S0039-9140(00)00653-6 
[71] R. Guidelli, F. Pergola, G. Raspi, Voltammetric Behavior of Nitrite Ion on Platinum in Neutral and Weakly Acidic Media, Anal. Chem. 44 (1972) 745-755. doi: 10.1021/ac60312a018 


\section{List of tables}

Table 1. Electrochemical parameters obtained from polarization curves using copper electrode in the absence and the presence of the $\mathrm{Ru}(\mathrm{III})-\mathrm{BSAP}-\mathrm{PLA}$ complex.

Table 2. Electrochemical impedance data obtained using CPE and CPE/Ru(III)-BSAP-PLA electrodes at different potentials in the absence of $\mathrm{NO}_{2}^{-}$.

Table 3. Electrochemical impedance data obtained using CPE and CG/Ru(III)-BSAP-PLA electrodes at different potentials in the presence of $\mathrm{NO}_{2}^{-}$.

Table 4. Electrochemical impedance data obtained using CPE/Ru-BSAP-PLA electrode at different temperatures in the presence of $\mathrm{NO}_{2}^{-}$.

\section{Figure captions}

Fig. 1 SEM microphotographs of the surface of the modified electrode.

Fig. 2 Polarization curves obtained using copper electrode in the absence and the presence of Ru(III)-BSAPPLA in $3 \% \mathrm{NaCl}$ solution

Fig. 3 EIS diagrams obtained using CPE/Ru(III)-BSAP-PLA electrode in the presence of $\mathrm{NO}_{2}^{-}\left(0.01 \mathrm{~mol} \mathrm{~L}^{-1}\right)$ at $\mathrm{pH}=7$ : a Nyquist plots; b Bode magnitude plots; c Bode phase plots

Fig. 4 Equivalent electrical circuits used to fit the impedance spectra: a CPE; b CPE/Ru(III)-BSAP-PLA electrode

Fig. 5 EIS diagrams obtained using $\mathrm{CPE} / \mathrm{Ru}(\mathrm{III})-\mathrm{BSAP}-\mathrm{PLA}$ electrode in the presence of $\mathrm{NO}_{2}^{-}\left(0.05 \mathrm{~mol} \mathrm{~L}^{-1}\right)$ at different temperature and $\mathrm{pH}=7$ : a Nyquist plots; $\mathbf{b}$ Bode magnitude plots; $\mathbf{c}$ Bode phase plots; applied potential $\mathrm{E}_{\mathrm{a}}=0.9 \mathrm{~V}$

Fig. 6 a Cyclic voltammograms obtained using CPE/Ru(III)-BSAP-PLA electrode in $0.1 \mathrm{~mol} \mathrm{~L}^{-1}$ $\mathrm{NaH}_{2} \mathrm{PO}_{4} / \mathrm{Na}_{2} \mathrm{HPO}_{4}$ solution containing $1.38 \times 10^{-2} \mathrm{~mol} \mathrm{~L}^{-1} \mathrm{NO}_{2}{ }^{-}$at different scan rates; $\mathbf{b}$ current vs. square root of scan rate; $\mathbf{c}$ potential vs. logv. Experimental conditions: $\mathrm{pH}=7 ;$ Temperature $=25^{\circ} \mathrm{C}$

Fig. 7 a,b Oxidation current versus $\mathrm{pH}$; c potential versus $\mathrm{pH}$ recorded with carbon paste electrode modified with $\mathrm{Ru}(\mathrm{III})-\mathrm{BSAP}-\mathrm{PLA}$ complex in $0.1 \mathrm{~mol} \mathrm{~L}{ }^{-1} \mathrm{NaH}_{2} \mathrm{PO}_{4} / \mathrm{Na}_{2} \mathrm{HPO}_{4}$. Experimental conditions: $\left[\mathrm{NO}_{2}^{-}\right]=1.59 \times 10^{-}$ ${ }^{4} \mathrm{~mol} \mathrm{~L}^{-1}$; Temperature $=25^{\circ} \mathrm{C}$; Scan rate $=0.020 \mathrm{~V} \mathrm{~s}^{-1}$

Fig. 8 a Cyclic voltammograms obtained with $\mathrm{CPE} / \mathrm{Ru}(\mathrm{III})$-BSAP-PLA modified electrode in $0.1 \mathrm{~mol} \mathrm{~L}^{-1}$ $\mathrm{NaH}_{2} \mathrm{PO}_{4} / \mathrm{Na}_{2} \mathrm{HPO}_{4}$ at different concentrations of nitrite; $\mathbf{b}$ Linear relationship between oxidation peak current and concentration of $\mathrm{NO}_{2}{ }^{-}$. Experimental conditions: $\mathrm{pH}=7$; Temperature $=25^{\circ} \mathrm{C}$; Scan rate $=0.020 \mathrm{~V} \mathrm{~s}^{-1}$ 
Table 1. Electrochemical parameters obtained from polarization curves using copper electrode in the absence and the presence of the Ru(III)-BSAP-PLA complex.

\begin{tabular}{llll}
\hline Parameters & \multicolumn{3}{l}{ Copper electrode } \\
\hline$[\mathrm{Ru}(\mathrm{III})-\mathrm{BSAP}-P L A]\left(\mathrm{mol} \mathrm{L}^{-1}\right)$ & 0 & $10^{-4}$ & $10^{-3}$ \\
\hline $\mathrm{E}_{\text {corr }}(\mathrm{V})$ & -0.200 & -0.150 & -0.158 \\
$\mathrm{i}_{\text {corr }}\left(\mu \mathrm{A} \mathrm{cm}{ }^{-2}\right)$ & 41 & 22 & 15 \\
$\mathrm{R}_{\mathrm{p}}\left(\Omega \mathrm{cm}^{2}\right)$ & 100 & 485 & 483 \\
$\mathrm{E} \%$ & - & 45.4 & 62.5 \\
\hline
\end{tabular}


Table 2. Electrochemical impedance data obtained using $\mathrm{CPE}$ and $\mathrm{CPE} / \mathrm{Ru}(\mathrm{III})-\mathrm{BSAP}-\mathrm{PLA}$ electrodes at different potentials in the absence of $\mathrm{NO}_{2}^{-}$.

\begin{tabular}{lll}
\hline Data for CPE/Ru- & $\mathrm{E}_{\mathrm{a}}(\mathrm{V})$ & $\mathrm{E}_{\mathrm{c}}(\mathrm{V})$
\end{tabular}

BSAP-PLA

(for CPE)

\begin{tabular}{|c|c|c|c|c|c|c|c|c|c|}
\hline & $\begin{array}{l}0.050^{*} \\
\left(0.180^{*}\right)\end{array}$ & $\begin{array}{l}0.100 \\
(0.230)\end{array}$ & $\begin{array}{l}0.150 \\
(0.280)\end{array}$ & $\begin{array}{l}0.200 \\
(0.330)\end{array}$ & $\begin{array}{l}0.250 \\
(0.380)\end{array}$ & $\begin{array}{l}0 \\
(0.130)\end{array}$ & $\begin{array}{l}-0.050 \\
(0.080)\end{array}$ & $\begin{array}{l}-0.100 \\
(0.030)\end{array}$ & $\begin{array}{l}-0.150 \\
(-0.020)\end{array}$ \\
\hline $\mathrm{R}_{\mathrm{s}}\left(\mathrm{k} \Omega \mathrm{cm}^{2}\right)$ & $\begin{array}{l}0.12 \\
(0.05)\end{array}$ & $\begin{array}{l}0.12 \\
(0.06)\end{array}$ & $\begin{array}{l}0.13 \\
(0.06)\end{array}$ & $\begin{array}{l}0.13 \\
(0.06)\end{array}$ & $\begin{array}{l}0.13 \\
(0.06)\end{array}$ & $\begin{array}{l}0.12 \\
(0.05)\end{array}$ & $\begin{array}{l}0.13 \\
(0.05)\end{array}$ & $\begin{array}{l}0.12 \\
(0.05)\end{array}$ & $\begin{array}{l}0.12 \\
(0.06)\end{array}$ \\
\hline $\mathrm{R}_{1}\left(\mathrm{k} \Omega \mathrm{cm}^{2}\right)$ & 274.96 & 435.61 & 401.20 & 356.35 & 295.08 & 299.23 & 221.96 & 141.31 & 108.68 \\
\hline$\left(W_{R}\right)$ & (1058) & $(2426)$ & (2644) & (2926) & $(3425)$ & $(751.2)$ & (1393) & $(1838)$ & (2088) \\
\hline $\mathrm{CPE}_{1}\left(\mu \mathrm{F} \mathrm{cm}{ }^{-2}\right)$ & 29.2 & 31.0 & 30.0 & 29.8 & 30.2 & 32.6 & 35.0 & 35.8 & 37.2 \\
\hline$N$ & $\begin{array}{l}0.430 \\
(0.709)\end{array}$ & $\begin{array}{l}0.464 \\
(0.701)\end{array}$ & $\begin{array}{l}0.468 \\
(0.703)\end{array}$ & $\begin{array}{l}0.471 \\
(0.705)\end{array}$ & $\begin{array}{l}0.476 \\
(0.703)\end{array}$ & $\begin{array}{l}0.414 \\
(0.698)\end{array}$ & $\begin{array}{l}0.431 \\
(0.693)\end{array}$ & $\begin{array}{l}0.440 \\
(0.695)\end{array}$ & $\begin{array}{l}0.446 \\
(0.694)\end{array}$ \\
\hline
\end{tabular}

$\mathrm{E}_{\mathrm{a}}$ : anodic potential $; \mathrm{E}_{\mathrm{c}}$ : cathodic potential, ${ }^{*} \mathrm{OCP}$ 
Table 3. Electrochemical impedance data obtained using CPE and CG/Ru(III)-BSAP-PLA electrodes at different potentials in the presence of $\mathrm{NO}_{2}^{-}$.

\begin{tabular}{|c|c|c|c|c|c|}
\hline \multirow{3}{*}{$\begin{array}{l}\text { Data for CPE/Ru- BSAP-PLA } \\
\text { (for CPE) }\end{array}$} & \multicolumn{5}{|l|}{$\mathrm{E}_{\mathrm{a}}(\mathrm{V})$} \\
\hline & $-0.110^{*}$ & -0.060 & -0.010 & 0.040 & 0.090 \\
\hline & $\left(-0.010^{*}\right)$ & $(0.040)$ & $(0.090)$ & $(0.140)$ & $(0.190)$ \\
\hline \multirow[t]{2}{*}{$\mathrm{R}_{\mathrm{s}}\left(\mathrm{k} \Omega \mathrm{cm}^{2}\right)$} & 0.12 & 0.12 & 0.12 & 0.13 & 0.13 \\
\hline & $(0.10)$ & $(0.09)$ & (0.09) & (0.09) & $(0.09)$ \\
\hline \multirow[t]{2}{*}{$\mathrm{R}_{1}\left(\mathrm{k} \Omega \mathrm{cm}^{2}\right)$} & 1.07 & 0.88 & 0.84 & 0.67 & 0.65 \\
\hline & $(257.24)$ & $(288.65)$ & (298.91) & (323.87) & $(360.25)$ \\
\hline \multirow[t]{2}{*}{$n_{1}$} & 0.31 & 0.27 & 0.27 & 0.35 & 0.35 \\
\hline & $(0.34)$ & $(0.36)$ & $(0.35)$ & $(0.33)$ & $(0.32)$ \\
\hline \multirow[t]{2}{*}{$\mathrm{CPE}_{1}\left(\mu \mathrm{F} \mathrm{cm}^{-2}\right)$} & 286.0 & 258.0 & 260.0 & 125.0 & 215.0 \\
\hline & $(32.5)$ & $(38.4)$ & $(45.6)$ & $(54.7)$ & $(62.4)$ \\
\hline $\mathrm{CPE}_{2}\left(\mu \mathrm{F} \mathrm{cm}^{-2}\right)$ & 40.1 & 41.2 & 34.2 & 67.7 & 62.5 \\
\hline $\mathrm{R}_{2}\left(\mathrm{k} \Omega \mathrm{cm}^{2}\right)$ & 1.18 & 1.01 & 1.72 & 2.19 & 3.42 \\
\hline$n_{2}$ & 1.00 & 1.00 & 1.00 & 0.89 & 0.90 \\
\hline
\end{tabular}


Table 4. Electrochemical impedance data obtained using CPE/Ru-BSAP-PLA electrode at different temperatures in the presence of $\mathrm{NO}_{2}^{-}$.

\begin{tabular}{llllllll}
\hline First semi-circle & \multicolumn{7}{c}{ Second semi-circle } \\
\hline Température & $\mathrm{R}_{\mathrm{s}}$ & $\mathrm{CPE}_{1}$ & $\mathrm{R}_{1}$ & $n_{1}$ & $\mathrm{R}_{2}$ & $\mathrm{Z}_{\mathrm{w}}$ & $n_{2}$ \\
$\left({ }^{\circ} \mathrm{C}\right)$ & $\left(\mathrm{k} \Omega \mathrm{cm}^{2}\right)$ & $\left(\mu \mathrm{F} \mathrm{cm}^{-2}\right)$ & $\left(\mathrm{k} \Omega \mathrm{cm}^{2}\right)$ & & $\left(\mathrm{k} \Omega \mathrm{cm}^{2}\right)$ & & \\
\hline 15 & 0.21 & 675 & 4.10 & 0.49 & 3.11 & 28.44 & 0.30 \\
20 & 0.20 & 753 & 4.06 & 0.48 & 2.12 & 15.03 & 0.27 \\
25 & 0.19 & 789 & 3.72 & 0.48 & 2.76 & 30.91 & 0.27 \\
30 & 0.18 & 813 & 3.26 & 0.49 & 1.33 & 7.20 & 0.27 \\
35 & 0.17 & 853 & 2.87 & 0.50 & 1.49 & 10.78 & 0.24 \\
40 & 0.15 & 938 & 2.74 & 0.49 & 0.90 & 4.11 & 0.23 \\
\hline
\end{tabular}



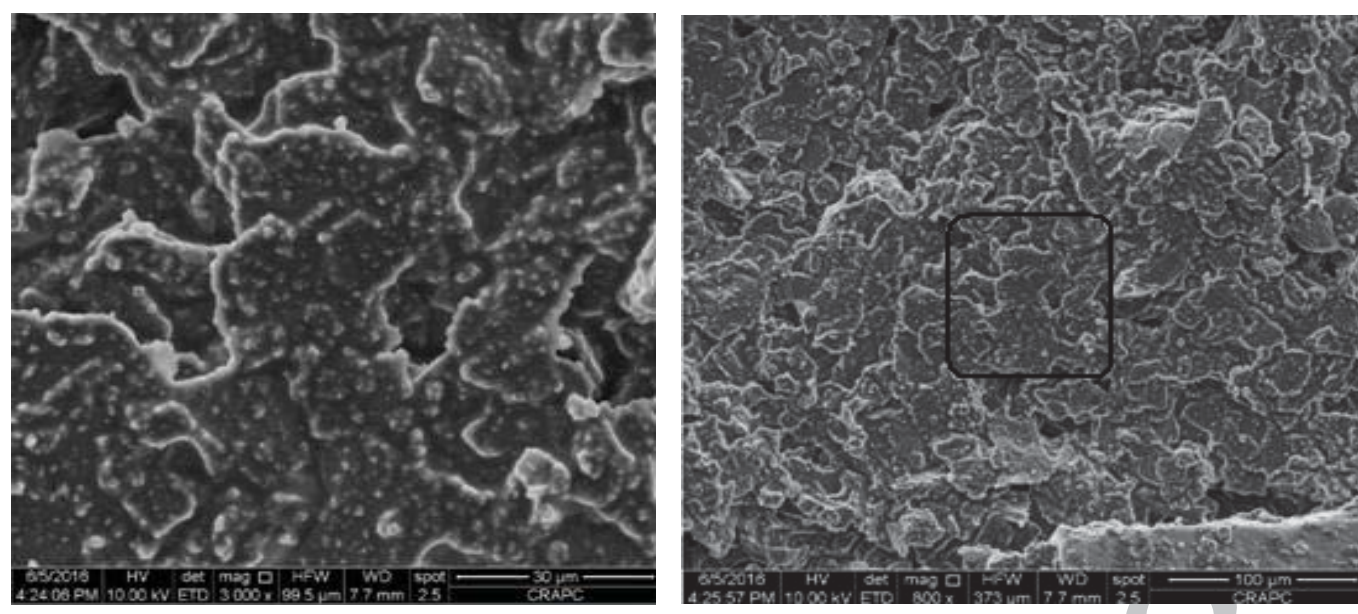

Fig. 1. 


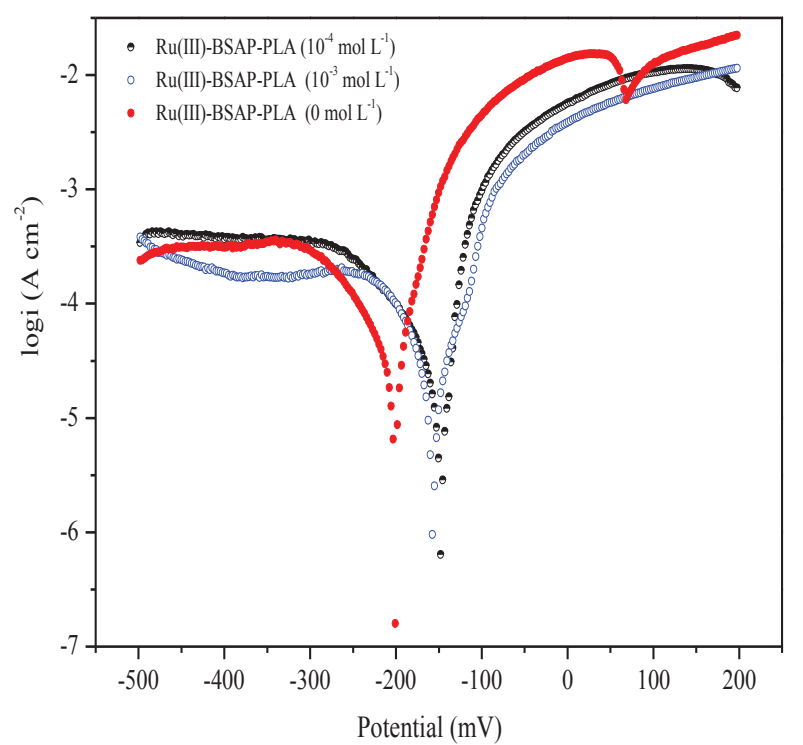

Fig. 2 

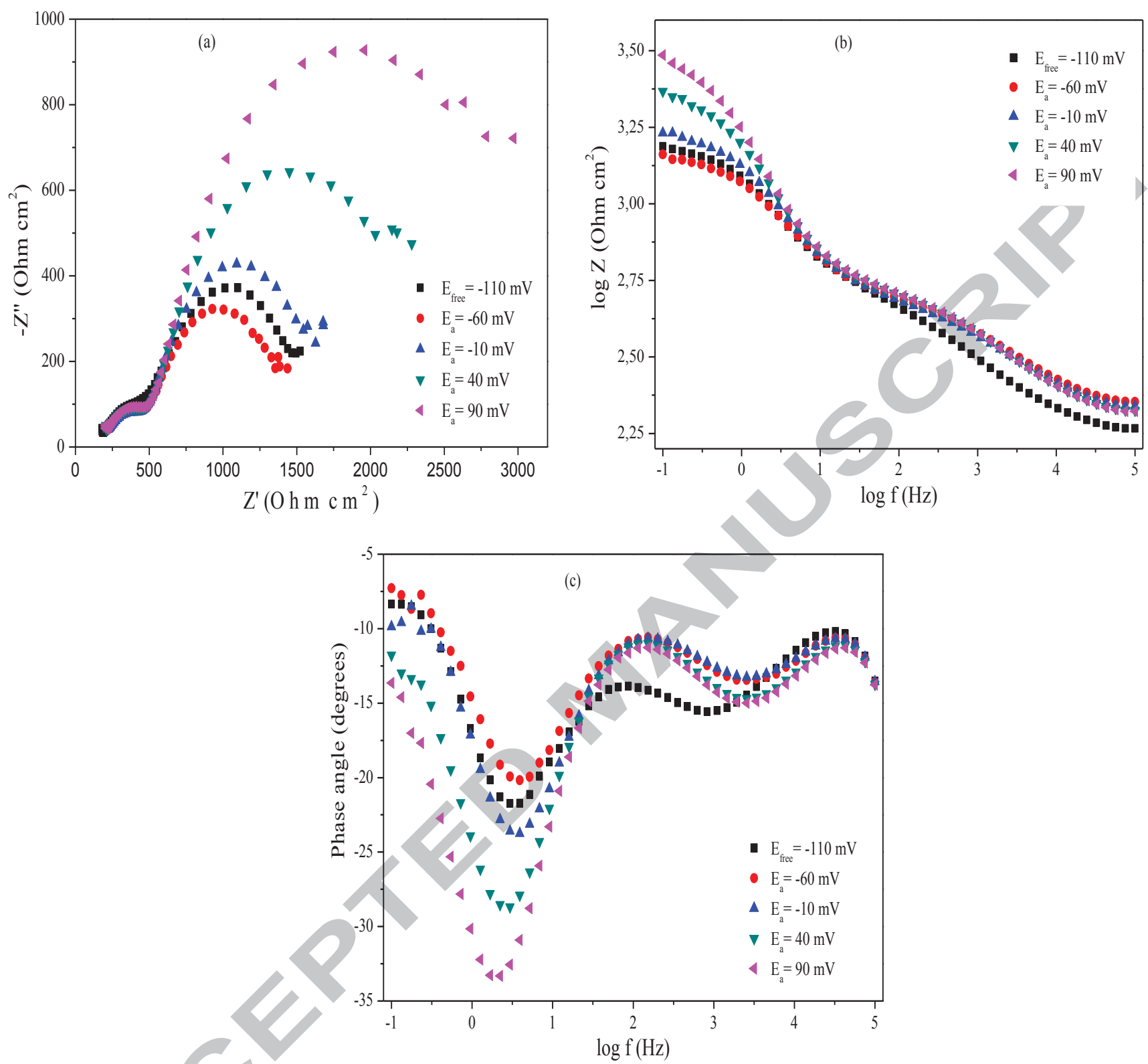

Fig. 3 


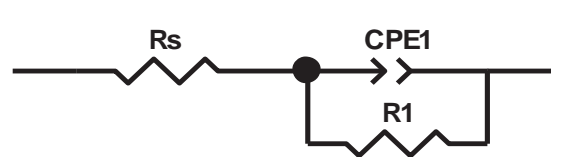

(a)

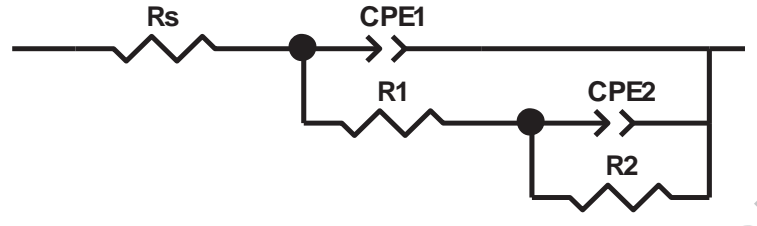

(b)

Fig. 4 

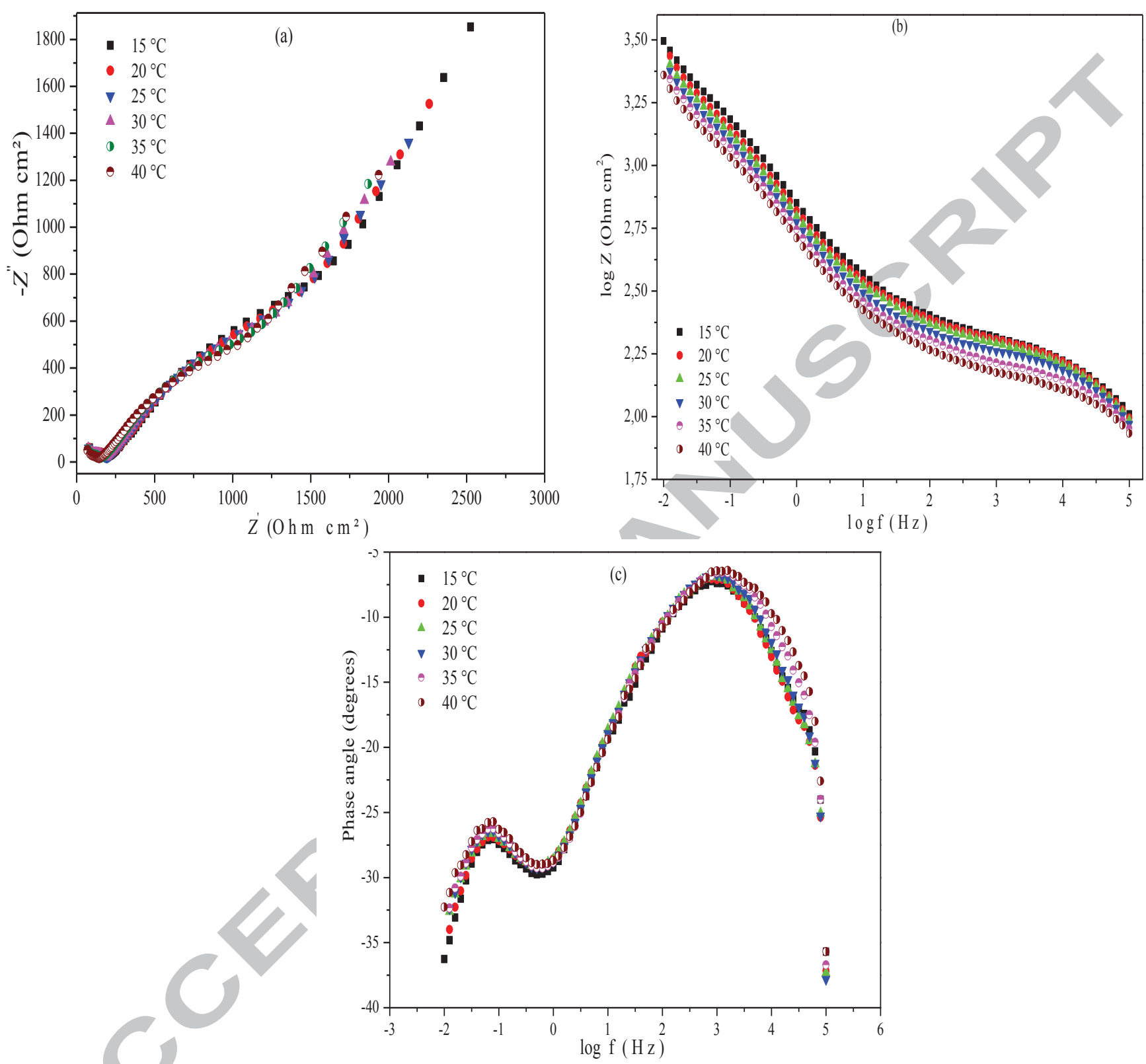

Fig. 5 


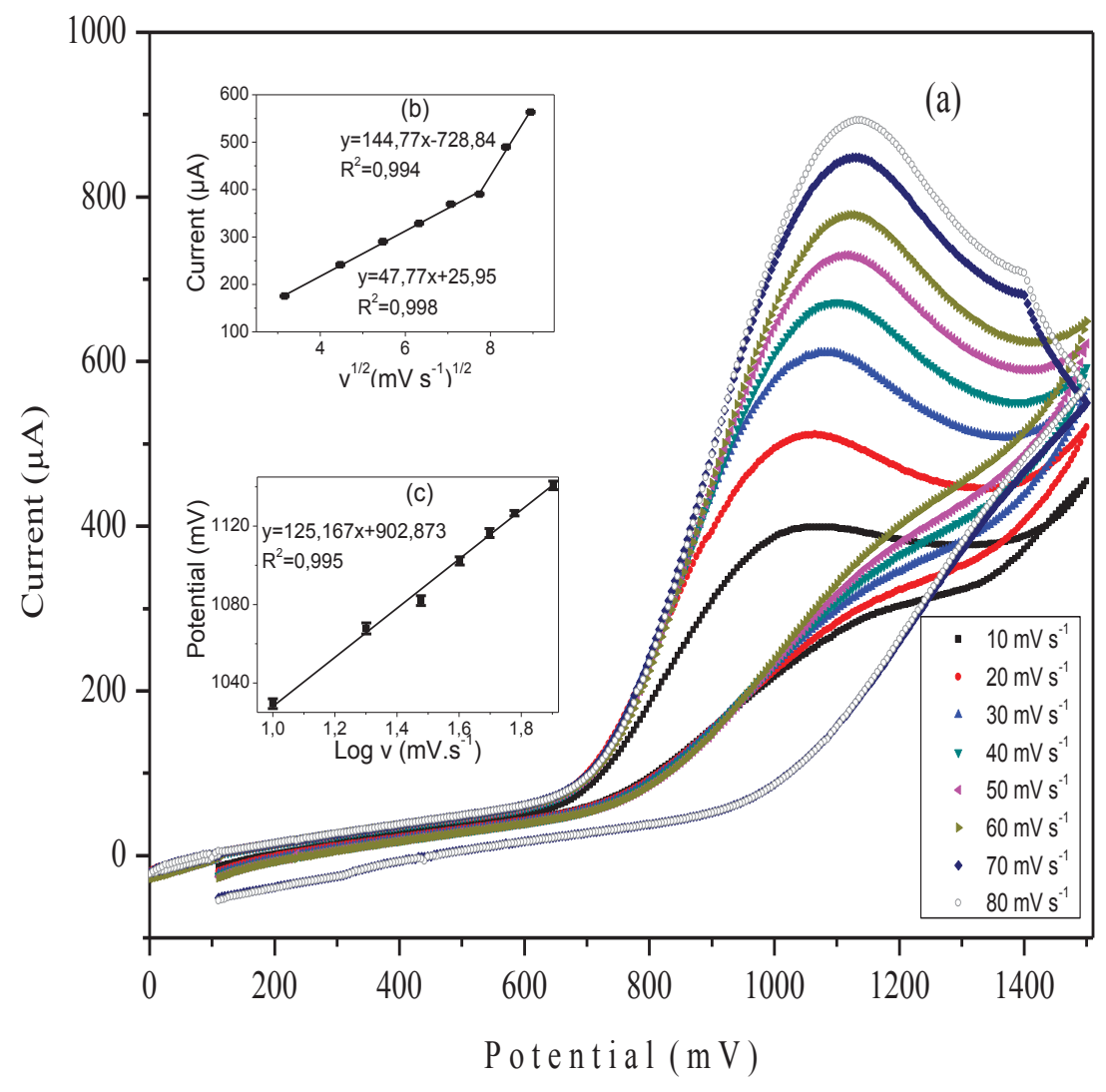




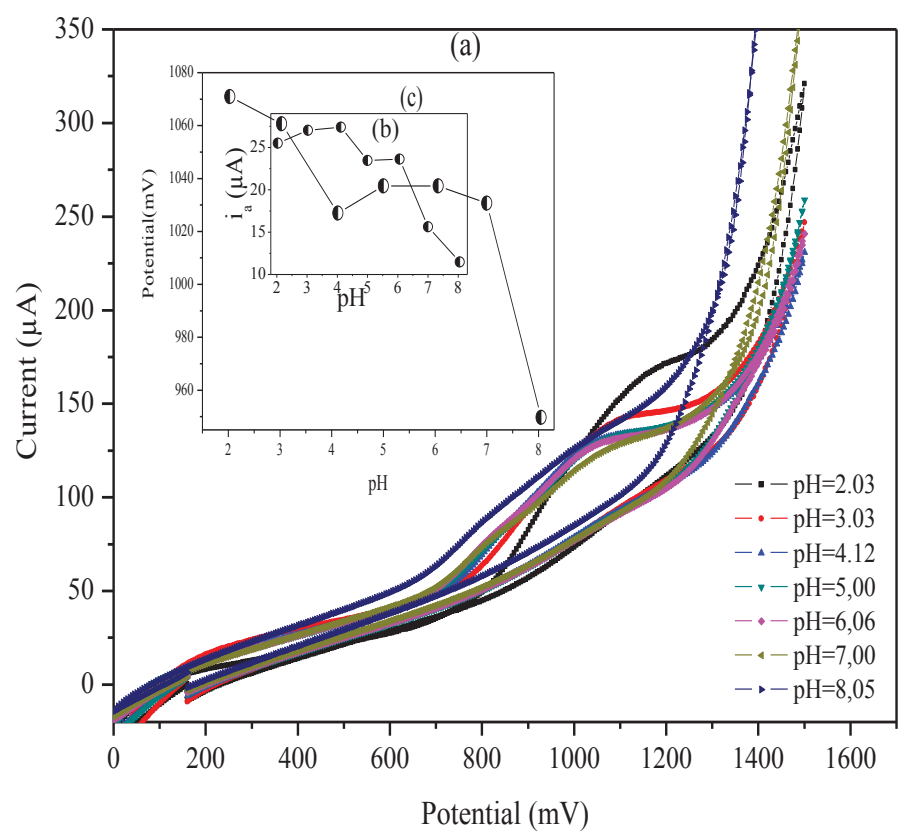

Fig. 7 


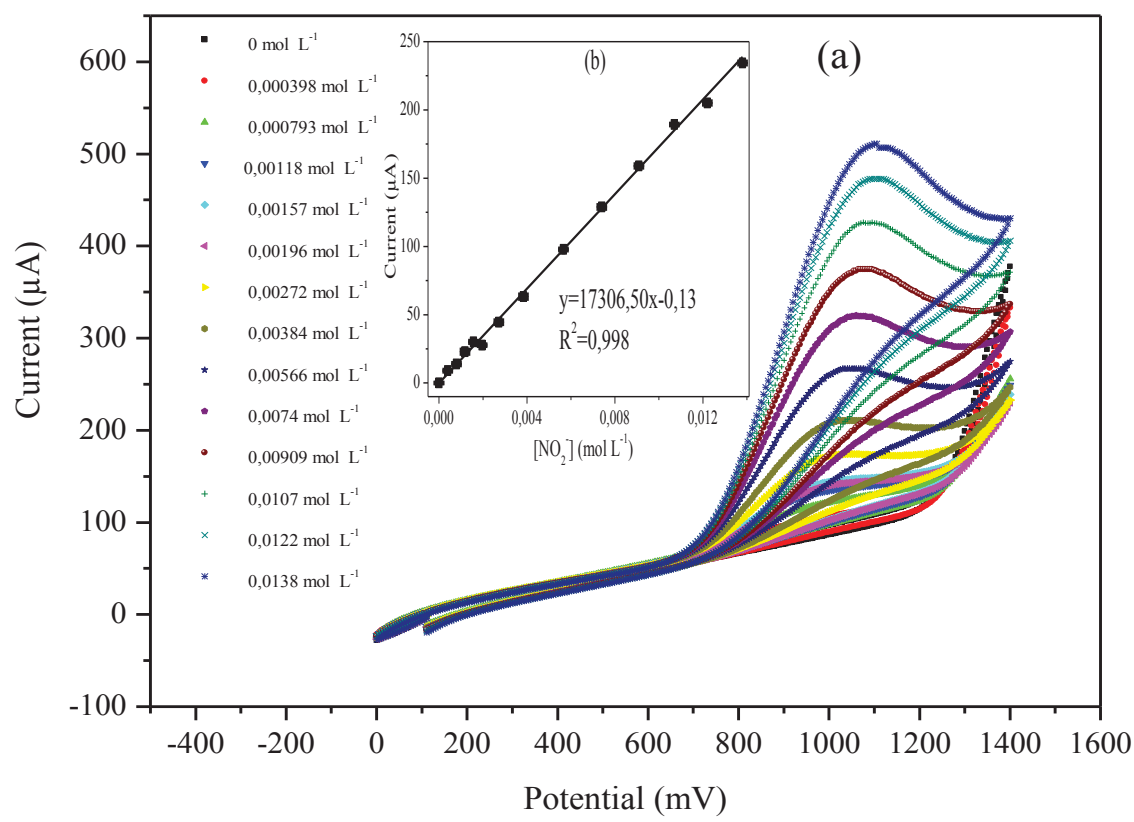

Fig. 8 


\section{Highlights}

- Modified $\mathrm{CPE} / \mathrm{Ru}(\mathrm{III})$ complex electrode was used as electrochemical sensor for the determination of nitrite.

- The behavior of nitrite on the surface of modified electrode was investigated in aqueous solution.

- Electrochemical impedance and cyclic voltammetry measurements were performed.

- The charge transfer resistance toward electro catalytic oxidation of nitrite decreased with increasing potentials and temperature.

- The modified electrode exhibited a wide linear range toward nitrite $\left(0-1.38 \times 10^{-2} \mathrm{~mol} \mathrm{~L}^{-1}\right)$ with a low detection limit of $1.4 \mu \mathrm{M}$. 

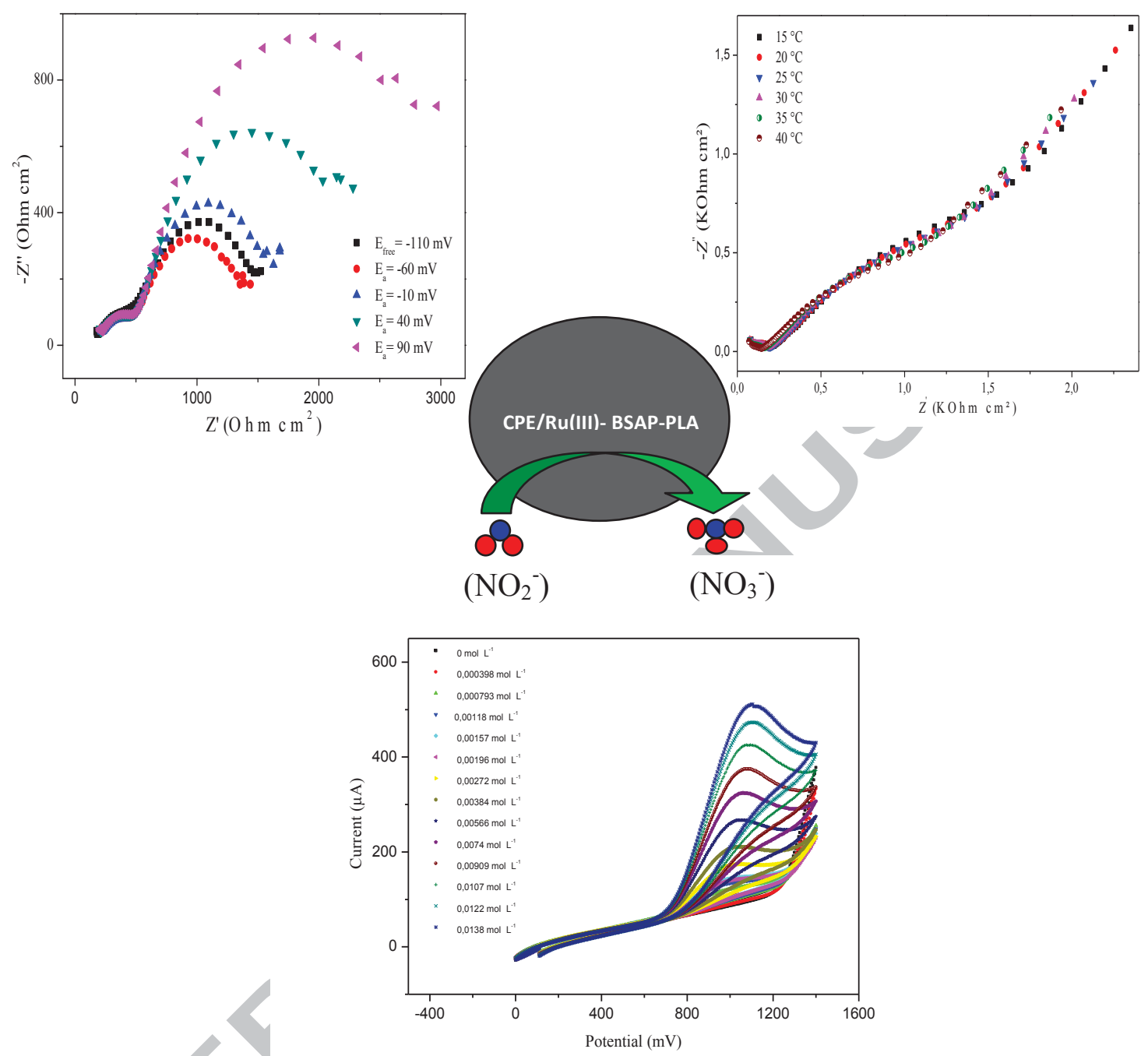